\title{
The Impacts of Socioeconomic Crisis in Portugal on Social Protection and Social Work Practices
}

\author{
Inês Casquilho-Martins
}

Citation: Casquilho-Martins, I. The Impacts of Socioeconomic Crisis in Portugal on Social Protection and Social Work Practices. Sustainability 2021, 13, 13198. https://doi.org/ $10.3390 /$ su132313198

Academic Editor: Paulo Reis Mourão

Received: 1 November 2021

Accepted: 24 November 2021

Published: 29 November 2021

Publisher's Note: MDPI stays neutral with regard to jurisdictional claims in published maps and institutional affiliations.

Copyright: (C) 2021 by the author. Licensee MDPI, Basel, Switzerland. This article is an open access article distributed under the terms and conditions of the Creative Commons Attribution (CC BY) license (https:// creativecommons.org/licenses/by/ $4.0 /)$.
Centro de Investigação e Estudos de Sociologia, Iscte-Instituto Universitário de Lisboa (CIES-Iscte), 1649-026 Lisboa, Portugal; ines.casquilho.martins@iscte-iul.pt

\begin{abstract}
The effects of the international crisis brought economic and financial risks, as well as consequences for human, social and sustainable development. This study aims to analyse the effects of social intervention with families since the 2008 crisis in Portugal. Through a qualitative approach, we conducted semi-structured interviews with social workers (23), to identify the main impacts of the crisis and the adopted social intervention practices. We highlight a new increase in social problems and the growth of vulnerable groups facing an unprepared social protection system. The Portuguese case reveals that the effects of austerity have shown a decline in the welfare and benefits system, leading to worsened social problems, such as increased poverty and unemployment, as well as social inequalities. Social Work was required to respond to these consequences, although organisational contexts and austerity measures constrained practitioners' autonomy. By reflecting on this critical period, we seek to contribute to better social protection and assistance models in the face of the current and future crisis. In this sense, Social Work practice ensures a means to guarantee fundamental rights and social justice, preparing social workers and social intervention for new challenges in crisis contexts.
\end{abstract}

Keywords: COVID-19; economic and social crisis; human rights; political models; social policy; social problems; social protection; social work; welfare state

\section{Introduction and Background}

The international crisis of 2008 marked the beginning of a period of great global difficulties. The concept of crisis is linked to the political, economic, and social scope contexts, which threaten the effort and the permanent demand for security and balance by individuals and social groups [1]. The severity of the 2008 crisis exceeded previous ones, plunging societies into hardship as a result of the effects of austerity policy making on a global scale, particularly in the European context [2]. The causes of the financial and economic crisis had different motives and diverse effects in European countries, with adjustment measures being more stringent in regions with lower competitiveness and higher deficits, and with harsher European decisions for peripheral countries than for the remaining member states [3].

The effects of fiscal rigidity measures produced changes in European policy trends [4,5] and weakened the living conditions of citizens in European countries, particularly in southern Europe [6,7]. Several studies have highlighted the consequences of the crisis on Mediterranean countries, such as fiscal austerity impacts [8], GDP decrease and worsening socioeconomic impacts [9], and labour market impacts [10]. The financial efforts increased the obligations of these countries with the banking systems, not contributing structurally to public budget balance, leading to more rigid consequences in the economic and social recovery of these countries [11,12].

The political austerity strategy in response to the economic crisis in Portugal started in 2010 with budgetary containment measures that were introduced by the Stability and Growth Programs. In 2011, these measures were expanded with the signing of the Economic 
and Financial Assistance Program, which changed the social protection model [13]. Thus, social recession and austerity were aggravated with the request for foreign financial aid and its implications for reducing public spending, particularly in social spending, resulting in an impoverishment of the population [14]. The impact of spending cuts and the privatisation of public management resulted in the reduction of social benefits, fewer social services, and less human and financial resources for the social protection system [13].

The context of financial, economic, social, and political crisis has resulted in the worsening of social phenomena such as social exclusion, inequality, and unemployment, among other social problems, that have worsened over the last decade $[15,16]$. Social policies and social transfers aim to protect the most vulnerable groups against social risks, ensuring economic and social cohesion, as well as the growth and sustainability of states. This social change process is gradual, guiding to economic, social, and environmental development, ensuring better life conditions for people and societies [17].

Neoliberalism led to the welfare state dismantlement, and to a breakdown of responsibilities, between the State, society, families, and the market [18]. Thus, we face a course of transformation between social actors that affects welfare and social protection, changing and producing novel forms of public intervention combined with private and civil society initiatives $[16,19]$. The privatisation of social protection services led to a weakening of the universality of social rights, deregulation, and profitability for the private sector in areas such as Social Security system [20]. Neoliberal policies have contributed to the increase in social inequalities, and the privatisation process in public policies diverges with the universal values of Social Work [21].

Some relevant Social Work studies have been performed on this theme, showing that these concerns were not limited to the Portuguese context but shared internationally [21-24], namely in member states heavily affected by crisis and austerity measures [25]. Deregulation and cuts in social protection increased social problems, created additional constraints to current living conditions and social welfare, therefore neglecting society instead of strengthening said social protection $[22,26]$. For citizens, the new social risks had a powerful impact on their needs, particularly for the most vulnerable group's future life opportunities [27]. Since the Maastricht Treaty (1992), that defined the construction of an external political agenda of cooperation between member states, several changes were introduced towards a Social Europe, aiming at a European Social Model, converging in social protection standards in counterbalance with a liberal economy. However, austerity ideologies across Europe seemed to place social policies as a second option and even classify them as an obstruction to European goals of socio-economic development and sustainability [28].

Social Work, as a human rights and well-being profession, has a commitment to societies, promoting social justice and people empowerment, and hence cannot be excluded from social-political matters $[29,30]$. The experience of social workers during this period allows to understand social intervention and therefore, promote better practices for an upcoming severer economic and social crisis, considering the implications and the new challenges that may arise to Social Work in this context [31]. It becomes necessary to rethink social intervention within the framework of social protection as the construction of an integrating social model and affirmation of human rights. Social workers should prioritise the political dimension of practice, considering its professional action to fight inequalities [32].

The social profession's role in public policies and social protection measures is, unquestionably, to fight social inequalities, poverty, and social exclusion [33-35]. In this setting, boundaries arise due to the limitation of resources and have often led to forms of welfare, placing barriers to the promotion of citizenship, and generating greater economic costs [15]. Unemployment and precarious employment are other aspects that defined the period of crisis and austerity, extending into Social Work itself $[24,36]$.

Additionally, the Global Definition of Social Work [37] approved in 2014 by the IFSW General Meeting and the IASSW General Assembly, and adopted in Portugal, enhances 
the profession to promote social change and development, addressing challenges to better living conditions and wellbeing. This prompts the discussion of relationship, reflection, and human action as key factors in Social Work intervention [38], which guide transformative practices that comply with promoting social well-being and combating social inequalities. Ethical and political issues lead to a critical perspective, which is a responsibility of Social Work $[39,40]$.

With crisis and austerity questioning the sustainability of the Portuguese Social Security System it has become increasingly pertinent to inform citizens and deconstruct fallacious myths [41]. In the field of Social Work, we considered it necessary to examine professional intervention during the 2008 crisis, based on the evidence of social workers, and contribute to better practice in future crisis scenarios. The impacts of economic crises have serious effects on social protection systems, pressuring public finances, leading to reflexions on the sustainability of welfare state models [42].

Based on interviews carried out with social workers, we present a systematisation of the results, allowing for their discussion. A total of four categories of analysis are established, reinforced by the results that characterise the intervention of social workers in times of austerity. Thus, the aim of this research is to analyse social impacts and intervention during and after the financial crisis in Portugal, to contribute to better practice and to a fair social protection system. This is a major concern considering we are currently going through a period of social emergency that forces us to rethink actions to prevent the weakening of fundamental rights and the sustainably of social services [43].

\section{Materials and Methods}

The research was conducted on a research project that analysed social intervention, as well as socioeconomic problems during the international crisis and austerity programmes. We utilised a qualitative approach as a method that contributes to improve policies, programs, projects, services, and social practices [44]. Considering the research plan, it focused on Portuguese social workers' perceptions of crisis impacts from 2008 to 2014 and the challenges after the austerity period.

The sample included 23 social workers, most of whom were women (20), with the following criteria: relevant experience in their area of training; professional activity at least since 2008; and experience in different fields of Social Work and organisations. The participants worked in public and non-governmental services, with professional experience in different fields of Social Work. The number of cases in the sample followed pre-defined criteria, selecting for a theoretical intentional sample [45] supported by a choice of cases, which, according to their level, may generate new ideas based on criteria previously established according to the theory. The intentional sampling helps to contest the limitation of not being able to have access to all the elements that make up the universe [45]. The interviews were directed to a concrete and finite number of subjects and participants, according to the methodological design of the research, reaching saturation [46]. We started from an initial contact with 30 possible interviewees, trying to maintain a balanced cohesion between the different sectors and areas of intervention. Some of the social workers contacted, even with a guarantee of anonymity and confidentiality, refused to participate, indicating the following reasons: (a) lack of knowledge of the topic; (b) need for superior authorisation; and (c) lack of time. There were also cases of absence of response. Subsequently, further contacts were made with other social workers who met the sample criteria. From a total of 42 contacted social workers, 25 agreed to participate and 23 interviews were carried out.

The 23 interviewees met the sampling requirements for achieving saturation of results: structural axes, representativeness, and saturation [47]. A diversity of socio-economic, temporal and spatial dimensions was guaranteed according to the criteria previously indicated through the heterogeneity of sectors of social intervention (e.g., public services, municipal councils, and non-profit organisations) and areas of professional activity (e.g., social assistance, health, education, and community development, among others); of 
professional experience that contemplated the entire period since the beginning of the crisis (e.g., minimum of ten years professional practice as a social worker) in different territories (e.g., social workers from different municipalities). By entering the limit of the number of cases due to the saturation of the sample, we simultaneously met the requirements of selection of subjects [47], which made it possible to validate results. The intention of this sampling is not to produce generalisations or infer statistical results, but to gain rich information about the data. More than establishing a certain number of cases on which results can be inferred, the sample seeks to collect information that adds knowledge through new data in the categories of analysis, reaching its saturation when the data do not provide new information.

Data were collected through semi-structured interviews [45], which allowed for the questioning of several professionals and enabled the improvement of data comparability and structuring. An interview script with twelve questions was performed (appendix 1), with an average duration of seventy minutes. The interviews were conducted from January to October 2017. We highlight that the interview as a research technique allowed for the collection of rich, intensive, and global information [46], in which the interviewees' discourses were important analysis elements of the socioeconomic reality and the social intervention. All questions were focused on the perception of the social workers according to their professional experience, while trying to distance from personal ideological positions, thus minimising this influence on the information collected.

Data collection implied that all participants were aware of the purpose of the interview and provided their consent about the shared information [48]. All interviews were anonymous, confidential, and voluntary. All interviewees signed an informed consent form, validating their agreement to participate in this study and consentient for data recording and processing.

To code the interviews, we followed pre-formulated categories and the relationships between the discourses, allowing to understand the relationship between the key concepts [45], categorising the collected data. For a more efficient and rigorous coding of the interviews, we used the Scientific Software Development GmbH-ATLAS.ti 8.2.30 (ATLAS.ti Scientific Software Development GmbH, Berlin). To ensure confidentiality, the ATLAS.ti 8.2.30 software randomly assigned the interview codes and was used to perform content analysis. The presentation of the analysed information follows Flick who advises that the results should enable comprehension, and therefore, should not be shared in their pure state [45]. Thus, we presented the results with developed systematised topics of the attained data. We highlight that the idea is not, however, to generalise results or closed conclusions, but to increase knowledge about a phenomenon or a social reality [49] and open future research perspectives.

\section{Results}

In this section, we present the findings based on data from semi-structured interviews, to describe social workers' perceptions of social intervention during and after the international crisis. The results were organised into sub-sections according to four categories: (1) Political and institutional context; (2) Main social problems; (3) Social support; and (4) Organisational procedures.

\subsection{Political and Institutional Context}

The interviewees considered the government, through its strategies, as an inhibiting element, constraining the response of social services and the political contribution of social workers. As referred by the interviewed participants, policy makers, whilst designing and planning key policies, did not recognise the public image of Social Work and, in this sense, the theoretical and practical knowledge of social workers had a limited influence.

The social workers interviewed shared their general perception about the characteristics of the Portuguese social protection model and its influence on professional practice. Several interviews mention the concern of the Portuguese government to respond to Eu- 
ropean expectations, following a neo-liberal ideology in which the sustainability of the financial system was prioritised, neglecting social sustainability and the living conditions of families.

According to them, an ideological assistance pattern on social protection policies motivated the government strategies during the austerity program and negatively affected social rights. The cuts in social expenditure were mainly executed by legislation changes in various social transfers such as Social Integration Income (RSI), old-age pensions, unemployment benefits, and family allowance, among others. It was also mentioned that from 2011 on, there was a transfer of public services from the state to the third sector, progressively reducing the direct role of the state in social protection. Moreover, non-profit organisations in Portugal financially depended on the state and, through public funding protocols, maintained their functions and support.

As a response to the most serious social needs, Programa de Emergência Social (PES) (the Social Emergence Plan) was implemented, albeit being extremely criticised by the interviewees. Criticism of PES was one of the most expressive results from the social workers' speeches. The most noticeable PES measure was the Emergency Food Program (social canteens) that was stated 42 times in the discourse of 17 interviewees. The interviewees considered PES as a contradiction to the realisation of social rights, due to its reductive nature to food support measures, eliminating other benefits.

'There is an ideological reversal of the path that was being taken, which has to do with the Social Emergency Plan. In this plan, one of the great flags was the creation of social canteens. So, there was a lot of money that was withdrawn from benefits and that reverted into meals for the population.' (SW20)

Most of the interviewees indicated that Social Work had no impact on political decisions, identifying several factors that led to this lack of political participation. Political government choices have led to a weakening of Social Work in its affirmation in a critical dimension, which was already debilitated. In the interviews, they expressed how weak political statement in social intervention was linked to ethical issues. Social workers complained that they were not recognised by policy makers, creating an image of aid professionals and thus, diminishing their role as political agents. There was a sense of frustration and stress caused by austerity measures, constraining the exercise of the profession to a less emancipatory action.

Most interviewees mentioned the inadequacy of labour conditions in non-profit organisations as an obstacle to social intervention. Professional exercise was conducted with precarity: low professional stability; low salaries; and hostile conditions in the workplace. Additionally, some interviewees declared demotivation, insecurity, harassment, and conformism while facing hierarchical powers, which affected the quality of their practice.

Regarding the changes after the austerity programme in Portugal, social workers stated that policy measures should have promoted a further strengthening of social protection. Although some improvements in social protection measures were indicated, such as wider access conditions to social benefits and the unfreezing of social pensions, most social workers considered that not enough alternatives were created to effectively recover from the effects of the crisis, especially in areas such as the labour market, poverty, and social exclusion.

\subsection{Main Social Problems}

An initial analysis of these topics denotes that the living standards and social wellbeing were a major concern to social workers, seeing an increase in social problems and specific vulnerable population groups in need (Table 1). 
Table 1. Main social problems and specific vulnerable groups.

\begin{tabular}{c} 
Main Social Problems \\
Unemployment (in 49 quotations, reported by 19 interviewees); \\
Housing debt (in 37 quotations, reported by 17 interviewees); \\
Low incomes (in 36 quotations, reported by 17 interviewees); \\
Hunger (in 18 quotations, reported by 13 interviewees); \\
Poverty / New poverty (in 18 quotations, reported by 10 interviewees); \\
Health conditions (in 17 quotations, reported by 9 interviewees); \\
Mental health (in 14 quotations, reported by 12 interviewees); \\
Job insecurity (in 13 quotations, reported by 10 interviewees); \\
Homelessness (in 9 quotations, reported by 5 interviewees); \\
Other household debts (in 8 quotations, reported by 6 interviewees); \\
Domestic violence (in 5 quotations, reported by 5 interviewees); \\
Others, particularly associated with crime increase (illicit commercial activities, addictions, \\
violence) and social isolation (in 8 quotations, referred to by 6 interviewees). \\
Main Vulnerable Groups \\
Elderly (in 30 quotations, reported by 12 interviewees); \\
Middle-class families (in 18 quotations, reported by 12 interviewees); \\
Poor families (in 14 quotations, reported by 10 interviewees); \\
Young people (in 7 quotations, reported by 2 interviewees). \\
Families with children in charge (in 13 quotations, reported by 9 interviewees); \\
\hline Source: Data retrieved by semantic analysis of semi-structured interviews analysed in Atlas.ti v.8.2.30.0.
\end{tabular}

Unemployment was the most common social problem, resulting in greater difficulties for families. Consequently, there was an increase in situations of poverty, identified as a "new poverty", associated with hunger situations and health problems, including mental health.

The interviewed social workers indicated that during the period of crisis and austerity, a different profile of people sought social services and responses, creating an additional challenge. The number of users in social services has grown considerably, with direct effects in the management of social workers' cases. Therefore, a new social user's profile on poverty and social exclusion (middle class; with high education levels; and who have never been unemployed) has emerged on social services with no police framework to ensure their protection.

This group profile was characterised by people of working age with a history of balanced incomes and higher qualifications but who, due to the crisis and resulting problems, namely unemployment, required assistance for the first time. There was also an increase in social support for young couples with children, young people and adults without employment or other sources of income, pre-retired unemployed adults, and elderly pensioners. Although the elderly was the least affected group by the rise in unemployment, according to social workers, they attempted to support their descendants financially.

\subsection{Social Support}

For the participants, austerity measures and social policies were not responding to the existing number of social assistance cases. They report that the restructuring and reduction of resources (financial and human) put the guarantee of rights at risk and weakened the social protection model. According to the data, we summarise the key support types and requests that were most available (Table 2). 
Table 2. Main requests for social support and responses/resources.

\begin{tabular}{|c|c|c|c|}
\hline $\begin{array}{l}\text { Most Mentioned } \\
\text { Social Support }\end{array}$ & Situations (Main Social Requests) & $\begin{array}{c}\text { Population (Main } \\
\text { Vulnerable Groups) }\end{array}$ & $\begin{array}{l}\text { Response Types (Main } \\
\text { Resources Available) }\end{array}$ \\
\hline Financial Support & $\begin{array}{l}\text { Payments of family expenses (housing } \\
\text { maintenance costs (water, electricity, gas, } \\
\text { etc.); support for education expenses } \\
\text { with children and youth (manuals and } \\
\text { school supplies, day-care, etc.). Increased } \\
\text { poverty by social benefits reductions. }\end{array}$ & $\begin{array}{l}\text { Unemployed } \\
\text { Middle-class families } \\
\text { Young parents }\end{array}$ & $\begin{array}{l}\text { Short financial support. } \\
\text { Meals at social canteens, food } \\
\text { bank, second-hand clothes. } \\
\text { Social Emergency Fund }\end{array}$ \\
\hline Food Support & $\begin{array}{l}\text { Request for food support for various } \\
\text { members of households. }\end{array}$ & $\begin{array}{c}\text { Unemployed } \\
\text { Single-parent families }\end{array}$ & $\begin{array}{l}\text { Meals at social canteens or } \\
\text { food bank }\end{array}$ \\
\hline Housing Support & $\begin{array}{l}\text { Non-compliance with payment of } \\
\text { instalments to the bank or income; } \\
\text { demand for lower-cost housing in ability } \\
\text { to meet payment; low, affordable housing } \\
\text { compared to household income. }\end{array}$ & $\begin{array}{l}\text { Unemployed } \\
\text { Low incomes families } \\
\text { Families with children }\end{array}$ & $\begin{array}{l}\text { One-off financial support for } \\
\text { debt regulation. Conventional } \\
\text { income programs or local } \\
\text { government beneficiaries. }\end{array}$ \\
\hline $\begin{array}{l}\text { Homelessness } \\
\text { Support }\end{array}$ & $\begin{array}{l}\text { Homelessness; loss of housing by } \\
\text { eviction actions. }\end{array}$ & $\begin{array}{l}\text { Unemployed } \\
\text { Migrants }\end{array}$ & Meals at social canteens \\
\hline Elderly Support & $\begin{array}{l}\text { Social-care services; inability to pay the } \\
\text { household expenses and social services } \\
\text { fees. }\end{array}$ & Elderly & $\begin{array}{l}\text { Referral to home care social } \\
\text { services. Accountability of the } \\
\text { family as caregivers. }\end{array}$ \\
\hline Medication Support & $\begin{array}{l}\text { Impossibility of acquiring medication; } \\
\text { non-compliance with dosage to prolong } \\
\text { the duration of the medication. }\end{array}$ & $\begin{array}{l}\text { Elderly; people with } \\
\text { disabilities. }\end{array}$ & $\begin{array}{l}\text { Medication support programs, } \\
\text { protocols with pharmacies. }\end{array}$ \\
\hline
\end{tabular}

Source: Data retrieved by semantic analysis of semi-structured interviews analysed in Atlas.ti v.8.2.30.0.

These requests were framed within those that were already regular, namely by the population who already utilised social services, and by the new publics, as shown in the previous sub-section. Application for financial support due to unemployment or a sharp decrease in household incomes was the major trend in social requests. Expenses with higher amounts, such as payment of rents or housing credit, were the reasons that led new publics to seek support from services. However, many of those requests were not guaranteed by the public social protection system and, in the impossibility of supporting financial applications, responses focussed on providing services and goods as an alternative. Through civil society solidarity, a large amount of material goods was provided, such as food and clothing (usually used) to support those who were in a more urgent situation of social vulnerability.

Therefore, the changes in the eligibility conditions in the social assistance programmes led to less financial support for families. However, the demand for support had increased and, with less access to these programmes, many social workers said that the state had resigned from its responsibility to support families in a dignified way. This perception was mainly held by social workers in public services. Social workers in non-profit organisations tended to offer responses through food banks or canteens, as these were the programmes that institutions had easiest access to. Financial support, which often unfolded into other types of support due to lack of funds, was the key request mentioned in the interviews.

Additionally, workers in public services criticised the cuts in the social protection system that were justified by the restructuring and reduction of resources, particularly human resources, and transferring social services public services to the third sector. In some cases, the lack of adequate resources resulted in social workers using their own money to work and undergoing non-paid extra hours of work.

\subsection{Organisational Procedures}

For interviewees, changing institutional or political decisions were deemed as arduous tasks due to the closed and bureaucratic nature of these structures. Although social workers 
consider it within their competencies to contribute to policy making and productive measures, their participation is limited because higher levels of decisions have already defined scopes and guidelines. A more managerial social intervention was often stated, being named by one interviewee as "administrative social assistance" (SW19).

Bureaucracy is indicated as one characteristic of the social protection model in times of austerity. Not only was protection and monitoring of the state to social actors lessened, but also the procedures instituted were more technocratic and time-consuming. Some social workers were limited to complying with socioeconomic ratios and following guideline instructions supported by a bureaucratic and functional model instead of a problemsolving model.

'It is not so easy, obviously, especially because they are very bureaucratic structures. (... ) The strategies are all defined when they get to us. Social Work is considered very important for a particular job, but then it is not valued.' (SW18)

Digital execution of functions to increase the rigour and speed of set procedures was directly connected with the concern of organisational and political goals. However, even with the modernisation and digitalisation of procedures, some problems arose, and one interviewee shared that if the institutions that monitored social support did not have the social security software, they had to go to the local social security service office to execute everything.

In most of the social organisations, the accumulation of cases by a case-manager was a limitation indicated by the participants. The participants considered that the reasonable number to ensure adequate follow-up and response was exceeded. Some showed the existence of hundreds of household cases per social worker, which meant thousands of people being assigned to the same professional. A lack of social counselling in social workers practice occurred due to this excessive number of cases managed by a single professional. Once more, a weak network of financial and human resources associated with a functionalist logic denoted limitation in the professional action. Furthermore, this aspect was aggravated by the organisation's preference to place trainees instead of hiring social workers with more experience, in order to cut expenses.

'There are some professionals with over 500 cases, which is an enormous responsibility. If those people just randomly decided to go over their full service, they had 500, and it is not people, it is cases. It is 500 families, all the responsibility of one person. And during this period, it was a person, not a team.' (SW4)

The composition of the work teams was also a differentiating criterion in the way social intervention was carried out. Interviewees integrated into teams composed of a larger number of social workers felt more responsiveness than those without or with fewer social workers. Another limitation was regarding teams whose intervention was not carried out from an interdisciplinary perspective, even when the intervention model requested so. Per example, in a team with a social worker and a psychologist, the social processes were simply divided by the professionals without considering the interdisciplinary implications.

\section{Discussion}

In Portugal, social policies were not defined by the theoretical and scientific knowledge of Social Work, but according to governmental programs and ideology of austerity, based on a model of budgetary rigidity to meet European demands. The results show the profession sought to respond to the emerging and urgent problems resulting in welfare spending and state provision of social services $[16,24]$.

The findings show that the context of crisis and austerity led to a greater fragility in ensuring some of the ethical principles of Social Work, with these not being a contribution to critical and political action. In this sense, regardless of the financial, political, and social context, the competence of social workers should drive practical intervention and scientific production focused on human valorisation, equity, and social justice $[39,50]$. The Social Emergency Plan (PES), as a social innovation model, focused on the needs of the most 
deprived and poverty-stricken citizens. However, interviewees did not agree with the measures of this programme, considering it did not prevent poverty and social exclusion.

The implemented social protection system was more focused on the dimension of support in extreme situations, rather than on the prevention of social needs and problems, prioritizing the financial sustainability of the model. Although these decisions sought to address the immediate effects of the crisis and austerity, in the medium and long term, they led to a regression of the achieved social development. This reality based on a functionalist model ideology was heightened at the beginning of the XXI century with the international crisis of 2008 [13,16,19].

The institutional constraints and poor working conditions were also relevant findings, being mentioned by social workers as a limiting factor to their professional practice. Not only were the service users in an unprotected position, but the social workers themselves believed to be facing professional vulnerability factors. The identification of the most vulnerable groups and the main social problems created an added pressure on the direct intervention work of social workers. The negative factors of the crisis and austerity multiply the risks in people's lives when the implemented austerity measures do not guarantee the necessary welfare protection $[21,31,51]$. The political strategies for a social emergency programme did not allow for a truly emancipating support, affecting the outcome of the direct intervention of social workers. Additionally, the problem of the sustainability of third sector organisations that continue to depend mostly on the state to maintain their activities and social projects is relevant to understand this issue.

Emergency contexts create a difficulty of action for professionals with the limitation of resources (material, logistic, and human) and, thus, affect the capability to manage them efficiently and effectively. Although social workers tried to work towards these goals, the lack of support by social policies and the state compromised their training and dedication.

An issue that became clear was the increase in requests for social support, the increase in people using social services in emergency situations, and the growth of social problems and people in need [52]. This showed that the Portuguese social protection system was not prepared to respond to the rising number of people who found themselves in a situation of poverty or social exclusion, nor to the particularities brought by this crisis. The social protection systems during crisis showed the need of social policies oriented to tackle the problems directly at their origin and not only to compensate for their negative impacts.

Social support, with a greater focus on emergency needs and bureaucratic models [53], has replaced more emancipatory practices and promoters of social rights and has led to unprofessionalisation [31,54]. The identification of the predominance in bureaucratic practices was associated with the lack of stability, and social workers had their professional practice conditioned when faced with pressure from the employers and an employability crisis [43].

Social Work strategies in contemporary organisational contexts are recognised as essential to promote the relationship between social workers and users. Thus, the participants criticised the political and institutional pressure, affirming that present policies and organisation framework were contrary to the purpose of Social Work. However, examples of new initiatives, leading to innovative opportunities for social intervention, were also mentioned. In these cases, interviewees believed that mobilisation for social change must be a collective action, because the impact at the individual level is reduced. This action must be supported by broad knowledge and information (legal, normative, institutional, and systemic, etc.), articulating the elements of decision-making [33,55].

Another identified aspect is the absence of social workers' participation in policy decision making, which undermines the goal of social justice [56]. The constraints felt by Portuguese social workers demonstrated that current political models and social control from the institutions conditioned their professional practice. The role of social workers was highlighted, as an integral part of its multi-dimensions and enabling the pursuit of social well-being through human relations and their potential for social and human development [30,33]. Nonetheless, in most interviews, Social Work was considered to have 
lost its claiming and critical dimension, as a result of a defensive practice [33,54] caused by low confidence and insecurity. This cannot be the exclusive responsibility of social workers due to the limitations imposed by the organisations and government [52].

The specificity of Social Work and the contact with various social agents, within the scope of social policies, places it as an effective element in protecting the most vulnerable groups, in social and economic cohesion, and the sustainability of communities and territories. The public opinion influence was also considered a disruptive element through the denial of collaboration between peers, namely between the professional and academic fields. The interviewees reported that their professional training placed them as privileged members for an active and informed participation in the promotion of social protection models and social policies. However, the functions attributed to the social workers did not take this expertise into consideration, being reduced to a caretaker role in a philanthropic perspective and not supported by a reinforced social solidarity model.

The critical and macro-level approach of Social Work decreased, which made fragile the profession and presents itself as a problem for reflection. In the last crisis and austerity period, the emergence of an opposite aspect to the deontological framework was identified. The loss of professional affirmation in professional action, particularly in the ethicalpolitical dimension, characterised intervention and needed to be reinforced.

Thus, challenges arise to contemporary practices that need the political involvement of the social worker as an essential action for future crisis. In this context, Social Work needs to participate guided by its ethical principles and by an intervention that responds to new social needs, as a promoter of social citizenship. Based on this study, relevant topics of attention for Social Work in this scenario were identified:

- The urgency of macro level practice and political participation with a reflexive and critical dimension, sustained by its foundations and experience.

- More participatory role and social participation with and amongst the several social participants.

- Closer proximity and visibility to policy makers, media, and public opinion.

- $\quad$ Strengthening the update of theoretical and methodological skills and strengthening their deontology.

- Welfare policies committed to promoting social justice and human rights.

- Investment in long-term sectoral and local policies for social development.

- Responses and social support that correspond to emancipatory models and sustainability in local and social services.

The contributions of Social Work, as a profession and as an academic area, are essential for the defence of human, social and collective interests, assessing and transforming resources and social welfare services. Thus, a logic of preventive action stands out in order to face existing social problems, requiring efforts to change and improve policies in legislative, institutional, and community contexts. Policy knowledge and professional competencies enable social workers to assess the feasibility of policies, identify resources, and develop or implement policy strategies. Additionally, the background of Social Work favours social interaction and the building of interpersonal relationships and connections between citizens, communities, and policy makers. However, social programmes and measures are designed and decided by the political power, and are not always efficiently evaluated. This lack of monitoring of implemented policies increases the difficulty to improve results, which could benefit from the knowledge of Social Work.

The profession's commitment to human rights, social justice and sustainable development cannot despise a critical approach in practice. Therefore, it is urgent to analyse the practice of social and ethical principles to guarantee welfare and citizenship rights in the face of neoliberal models. The theoretical-methodological and ethical-political dimensions are increasingly important in the current crisis, and the mission of Social Work intervention can only be fulfilled by correcting limitations of the past and preparing to face forthcoming challenges. 
The enhancement of networks and relationships between people and communities [57] are important contributions against neoliberal logics of action and for a reconfiguration of the contemporary capitalism, based on social reproduction as an individual and collective relations process [58]. These are relevant to promote socio-economic transformations and human development [59] and to potentialize an alternative model based on democratising welfare institutions [60].

In particular, the socio-economic impacts of this new crisis and the preparation of social protection systems to face the new challenges of emerging crises lead us to reflect on the consequences of the State's lack of commitment to improve social protection for citizens [41]. Currently, the effects of the 2008 crisis are still present because the Portuguese Social Security System has not fully recovered from the last financial and economic crisis [25]. Therefore, we are facing a lower capacity of social protection in the pandemic context to deal with poverty, low income, unemployment, and precarious work [61].

Some limitations to this study should be mentioned. As a qualitative study with a small sample of interviewed social workers, the results cannot be generalised. However, through the saturation of the analysed and collected interview data, convergent results were found, which allowed to analyse a pattern of answers, leading to the identification of common perceptions on the explored topics. Another limitation was the lack of Social Work literature and research on social practice during the 2008 international crisis. Most studies on the economic and financial crisis in Portugal were undertaken by other scientific areas, such as sociology, economy, and political science. Thus, this was also an opportunity to engage Social Work research with new objects of study and indicators [62].

By analysing the context of the 2008 international crisis, we understand how intervention can be improved in new crisis situations, such as the one currently experienced with the COVID-19 pandemic. While recognising that crises have different origins and response models, patterns can be found in past events that confirm the need for further development. Recent crises reveal the continuous worsening of social problems and the increase in social inequalities $[32,63]$. We see that government responses are dependent on funding from European institutions, therefore having to follow specific conventions to manage the socio-economic impacts. In the Portuguese case, the economic and financial crisis has led to a social and political crisis. In the current ideological and political framework context, the health, economic and social crisis in Portugal, has recently resulted in a political crisis that leaves open the possibility of partial repetition and transition to neoliberal policies. Based on this study, further research will be conducted to compare the social protection system during the pandemic crisis to understand whether there has been a new reconfiguration of the social protection response and its effects.

\section{Conclusions}

In an era of globalisation, the worsening of social phenomena such as poverty, social exclusion, and inequalities alert to the importance of analysis of social policies, methodologies of social intervention and of Social Work itself, in order to reach social justice [29,34,39], assuring equal opportunities and social participation. As an instrument of welfare state, social policies contribute to economic growth and sustainability by acting against market contingencies and against the impacts of global changes.

The international crisis pressured the European Union and the European Social Model for reforms that, though not formally, interfered with the effectiveness of the social protection system. The Portuguese case shows how the impacts of austerity correlate to a greater decrease in benefits and support in the field of social rights. The Government's political options in the international crisis of 2008 focus the priority on a model of budgetary rigidity with spending cuts in social protection fields. Considering the nature of continuous change of contemporary societies, the social protection system and political decisions should consider the Social Work knowledge and the participation of social workers in the design, implementation, and evaluation of social policies. The focus on important preventive policies avoids the aggravation of social problems, namely in the areas of social security, 
education, health, and housing, functioning as an intervention mechanism in the face of socio-economic risk contexts [35].

The current COVID-19 pandemic crisis poses additional worries and challenges identified by social workers, most of them directly emerging from the lack of social protection and financial resources for social services to respond to urgent social needs $[43,63]$. Social problems and vulnerable groups are more exposed, being clear the urgent necessity of developing well-structured and strong social protection policies to guarantee social and human rights.

Therefore, social protection models should seek to promote sustainable alternatives and viable political and social responses for citizens, becoming a collective responsibility in which social professions have an important role. The points discussed throughout this analysis invite practitioners and researchers in the fields of social protection and social policies, to participate with their updated knowledge and skills in order to strengthen a policy practice that enables social change and defends fundamental rights, especially in the most critical periods.

Funding: This research received no external funding.

Institutional Review Board Statement: The study was conducted according to the guidelines of the Declaration of Helsinki and approved by Centro de Investigação e Estudos de Sociologia (CIES-Iscte).

Informed Consent Statement: Informed consent was obtained from all subjects involved in the study.

Data Availability Statement: Not applicable.

Conflicts of Interest: The author declares no conflict of interest.

\section{References}

1. Ferreira, A.C. Política e Sociedad-Teoria Social em Tempo de Austeridade; Vida Económica: Porto, Portugal, 2014.

2. Soromenho-Marques, V. Portugal na Queda da Europa; Temas e Debates: Lisboa, Portugal, 2014.

3. Varoufakis, Y.; Holland, S. A modest proposal for resolving the Eurozone crisis. Intereconomics 2012, 47, 240-247. [CrossRef]

4. Bontout, O.; Lokajickova, T. Social Protection Budgets in the Crisis in the EU. European Commission Working Paper 1/2013. Available online: https:/ / op.europa.eu/en/publication-detail/- / publication/c339cf4b-105c-4954-bbcc-2bb40811c4b8/languageen/format-PDF (accessed on 30 September 2021).

5. OECD. Society at a Glance 2014: OECD Social Indicators; OECD Publishing: Paris, France, 2014.

6. Perez, S.A.; Matsaganis, E. The Political Economy of Austerity in Southern Europe. New Politics Econ. 2018, 23, 192-207. [CrossRef]

7. Morlino, L.; Sottilotta, C.E. Southern Europe and the Eurozone Crisis Negotiations: Preference Formation and Contested Issues. S. Eur. Soc. Politics 2019, 24, 1-28. [CrossRef]

8. Zezza, G. The impact of fiscal austerity in the Eurozone. Rev. Keynes. Econ. 2012, 1, 37-54. [CrossRef]

9. Serapioni, M.; Hespanha, P. Crisis and Austerity in Southern Europe: Impact on Economies and Societies. e-cadernos CES 2019, 31. [CrossRef]

10. Carnevali, E.; Godin, A.; Lucarelli, S.; Passarella, M.V. Productivity growth, Smith effects and Ricardo effects in Euro Area's manufacturing industries. Metroeconomica 2019, 71, 129-155. [CrossRef]

11. Blyth, M. Austeridade-A História de Uma Ideia Perigosa; Quetzal: Lisboa, Portugal, 2013.

12. Zamora-Kapoor, A.; Coller, X. The Effects of the Crisis. Am. Behav. Sci. 2014, 58, 1511-1516. [CrossRef]

13. Hespanha, P.; Ferreira, S.; Pacheco, V. O Estado, crise e reformas. In A Anatomia da Crise: Identificar os Problemas para Construir Alternativas; Observatório sobre Crises e Alternativas; Centro de Estudos Sociais: Coimbra, Portugal, 2013; pp. 161-249.

14. Rodrigues, M.L. A Execução do Memorando de Entendimento. In Governar com a Troika Políticas Públicas em Tempos de Austeridade; Silva, P.A., Ed.; Almedina: Coimbra, Portugal, 2015.

15. Vega, N.R. El trabajo social en tiempos de crisis. In Trabajo Social en el Siglo XXI-Una Perspectiva Internacional Comparada; Seller, E.P., Martinez-Román, M.A., Eds.; Editoral Grupo 5: Madrid, Spain, 2014; pp. 97-108.

16. Capucha, L. Impacto do Programa de Austeridade na pobreza em Portugal. In Governar com a Troika Políticas Públicas em Tempos de Austeridade; Rodrigues, M.L., Silva, P.A., Eds.; Almedina: Coimbra, Portugal, 2015; pp. 457-468.

17. Rocha, H.B. Social Work Practices and the Ecological Sustainability of Socially Vulnerable Communities. Sustainability 2018, 10, 1312. [CrossRef]

18. Carvalho, M.I. Ética Aplicada ao Serviço Social; Pactor: Lisboa, Portugal, 2016.

19. Estanque, E. O Estado Social em Causa: Instituições sociais, políticas sociais e movimentos sociolaborais no contexto europeu. Finisterra-Revista de Reflexão e Crítica 2012, 73, 39-80.

20. Santos, C. Rendimento de facto mínimo? Estado, Assistência e Questão Social. In A segurança social é sustentável-Trabalho, Estado e Segurança Social em Portugal; Varela, R., Ed.; Bertrand Editora: Lisboa, Portugal, 2013; pp. 315-334. 
21. Spolander, G.; Engelbrecht, L.; Martin, L.; Strydom, M.; Pervova, I.; Marjanen, P.; Tani, P.; Sicora, A.; Adaikalam, F. The implications of neoliberalism for social work: Reflections from a six-country international research collaboration. Int. Soc. Work 2014, 57, 301-312. [CrossRef]

22. Ioakimidis, V.; Santos, C.C.; Herrero, I.M. Reconceptualizing social work in times of crisis: An examination of the cases of Greece, Spain and Portugal. Int. Soc. Work 2014, 57, 285-300. [CrossRef]

23. Martinez-Román, M.A.; Domenech-López, Y. Ciudadanía y trabajo social. In Trabajo Social en el Siglo XXI-Una Perspectiva Internacional Comparada; Seller, E.P., Martinez-Román, M.A., Eds.; Editoral Grupo 5: Madrid, Spain, 2014; pp. $109-116$.

24. Ornellas, A.; Spolander, G.; Engelbrecht, L.K.; Sicora, A.; Pervova, I.; Martínez-Román, M.-A.; Law, A.K.; Shajahan, P.; Guerreiro, M.D.D.; Casanova, J.L.; et al. Mapping social work across 10 countries: Structure, intervention, identity and challenges. Int. Soc. Work 2019, 62, 1183-1197. [CrossRef]

25. Casquilho-Martins, I. Estado, Proteção Social e Serviço Social: Tendências atuais e desafios à mudança. In Do Conhecimento à ação em Serviço Social: Contributos para Uma Intervenção Profissional Sustentada; Bento, M.C., Fernandes, A.I.L., Eds.; 5 Livros: Porto, Portugal, 2020; pp. 73-94.

26. Pentaraki, M. The executive committee of the Greek Professional Association of Social Work in an age of austerity: Examining its response. Eur. J. Soc. Work 2013, 18, 140-155. [CrossRef]

27. Taylor-Gooby, P. New Risks, New Welfare: The Transformation of the European Welfare State; Oxford University Press: Oxford, UK, 2004.

28. Menz, G. Whatever Happened to Social Europe? The Three-Pronged Attack on European Social. In Social Policy and the Eurocrisis: Quo Vadis Social Europe; Crespy, A., Menz, G., Eds.; Palgrave Macmillan: Basingstoke, UK, 2015; pp. 45-62.

29. Clark, C.L. Social Work Ethics. Politics, Principles and Practice; Palgrave Macmillan: Basingstoke, UK, 2000.

30. Adams, R.; Dominelli, L.; Payne, M. Transforming Social Work. In Social Work Futures-Crossing Boundaries Transforming Practice; Adams, R., Dominelli, L., Payne, M., Eds.; Palgrave Macmillan: Basingstoke, UK, 2005; pp. 1-18.

31. Ornellas, A.; Engelbrecht, L.; Atamtürk, E. The fourfold neoliberal impact on social work and why this matters in times of the COVID-19 pandemic and beyond. Soc. Work 2020, 56, 235. [CrossRef]

32. Andrade, M. Campo de Intervenção do Serviço Social: Autonomias e heteronomias do agir. Intervenção Soc. 2001, 23-24, 217-232.

33. Thompson, N. Understanding Social Work, 3rd ed.; Palgrave Macmillan: Basingstoke, UK, 2009.

34. Colby, I. Social welfare policy as a form of social justice. In Social Work and Social Policy: Advancing the Principles of Economics and Social Justice; Colby, I., Dulmus, C.N., Sowers, K.M., Eds.; Wiley: New York, NY, USA, 2012; pp. 1-20.

35. Novo-Corti, I.; Tîrcă, D.-M.; Ziolo, M.; Picatoste, X. Social Effects of Economic Crisis: Risk of Exclusion. An Overview of the European Context. Sustainabiltiy 2019, 11, 336. [CrossRef]

36. De Castro, A.M.M.; Tomé, R.M.; Carrara, V.A. A emigração dos assistentes sociais portugueses: Faces do trabalho e do desemprego em tempos de crise e austeridade. Serv. Soc. Soc. 2015, 121, 95-124. [CrossRef]

37. International Federation of Social Workers. Global Definition of Social Work. July 2014. Available online: https://www.ifsw.org/ what-is-social-work/global-definition-of-social-work/ (accessed on 22 November 2021).

38. Payne, M. Social Work Process. In Social Work Futures-Crossing Boundaries Transforming Practice; Adams, R., Dominelli, L., Payne, M., Eds.; Palgrave Macmillan: Basingstoke, UK, 2005; pp. 19-35.

39. Banks, S. Ethics in an age of austerity: Social work and the evolving New Public Management. J. Soc. Interv. Theory Pract. 2011, 20, 5-23. [CrossRef]

40. Jones, D.N.; Truell, R. The Global Agenda for Social Work and Social Development: A place to link together and be effective in a globalized world. Int. Soc. Work 2012, 55, 454-472. [CrossRef]

41. Silva, P.A.; Pereira, M.T. Cuidar do Futuro. Os Mitos do Estado Social Português; Clube do Autor: Lisboa, Portugal, 2015.

42. Carè, R.; De Lisa, R. Social Impact Bonds for a Sustainable Welfare State: The Role of Enabling Factors. Sustainability 2019, 11, 2884. [CrossRef]

43. Redondo-Sama, G.; Matulic, V.; Munté-Pascual, A.; De Vicente, I. Social Work During the COVID-19 Crisis: Responding to Urgent Social Needs. Sustainability 2020, 12, 8595. [CrossRef]

44. Shaw, I.; Gould, N. Qualitative Research in Social Work; Sage Publications: London, UK, 2001.

45. Flick, U. Métodos Qualitativos na Investigação Científica; Monitor: Lisboa, Portugal, 2005.

46. Muñoz, C.D.; Civera, C.N. La entrevista como técnica de investigación. In Métodos y Técnicas de Investigación en Trabajo Social; Civera, C.N., Diez, E.R., Eds.; Editorial Grupo 5: Madrid, Spain, 2015; pp. 155-174.

47. Pedreño, M.H. La muestra en la investigación cualitativa. In Métodos y Técnicas de Investigación en Trabajo Social; Civera, C.N., Diez, E.R., Eds.; Editorial Grupo 5: Madrid, Spain, 2015; pp. 77-94.

48. Babbie, E. The Basics of Social Research, 7th ed.; Cengage Learning: Boston, MA, USA, 2017.

49. Vilelas, J. Investigação-O Processo de Construção do Conhecimento, 3rd ed.; Edições Sílabo: Lisboa, Portugal, 2020.

50. Branco, F.; Amaro, I. As práticas do "Serviço Social activo" no âmbito das novas tendências da política social: Uma perspectiva portuguesa. Serv. Soc. Soc. 2011, 108, 656-679. [CrossRef]

51. Truell, R. How Are Portugal's Cuts Affecting Social Workers? The Guardian. 19 November 2012. Available online: http: //www.theguardian.com/social-care-network/2012/nov/19/portugal-cuts-social-work (accessed on 29 August 2021).

52. Carvalho, M.I.; Pinto, C. Desafios do Serviço Social na atualidade em Portugal. Serv. Soc. Soc. 2015, 121, 66-94. [CrossRef] 
53. Farrell, C.; Morris, J. The 'Neo-Bureaucratic' State: Professionals, Managers and Professional Managers in Schools, General Practices and Social Work. Organization 2003, 10, 129-156. [CrossRef]

54. Amaro, M.I. Urgências e Emergências do Serviço Social-Fundamentos da Profissão na Contemporaneidade; Universidade Católica: Lisboa, Portugal, 2012.

55. Howe, D. A Brief Introduction of Social Work Theory; Palgrave Macmillan: Basingstoke, UK, 2009.

56. Figueira-McDonough, J. Policy Practice: The Neglected Side of Social Work Intervention. Soc. Work 1993, 38, 179-188. [CrossRef]

57. Bollier, D.; Helfrich, S. Free, Fair, and Alive: The Insurgent Power of the Commons; New Society Publishers: Gabriola Island, BC, Canada, 2019.

58. Lucarelli, S.; Vercellone, C. The Thesis of Cognitive Capitalism. New Research Perspectives. An Introduction. Knowl. Cult. 2014, $1,15-27$.

59. Fumagalli, A.; Morini, C. Anthropomorphic Capital and Commonwealth Value. Front. Sociol. 2020, 5, 5. [CrossRef]

60. Vercellone, C. From the Crisis to the 'Welfare of the Common' as a New Mode of Production. Theory Cult. Soc. 2015, 32, 85-99. [CrossRef]

61. Pereirinha, J.A.C.; Pereira, E. Social resilience and welfare systems under COVID-19: A European comparative perspective. Glob. Soc. Policy 2021. [CrossRef]

62. Álvarez-Pérez, P.; Ferreira, J.M. La construcción teórica del objeto en Trabajo Social: Un análisis empírico basado en la formación de segundo ciclo. Comunitania 2021, 21,61-95. [CrossRef]

63. Cardoso, J.; Vilar, D.; Casquilho-Martins, I. Relatório do Estudo-Desafios ao Serviço Social no Contexto da COVID-19. Centro Lusíada de Investigação em Serviço Social e Intervenção Social. 2020. Available online: https:/ /www.lis.ulusiada.pt/Portals/ News/docsexternos/docs/relatorio_desafios_ao_servico_social_no_contexto_da_covid-19.pdf (accessed on 29 August 2021). 